Animal Health Research Institute, Damanhour Branch.

\title{
A CASE REPORT: COPPER DEFICIENCY SYNDROME IN A BUFFALO FARM IN BEHAIRA GOVERNORATE
}

(With One Table)

By

\section{AMANY ABDEL RAHMAN SALLAM and A.F. ABDEL MOGHNEY}

(Received at 1/8/2009)

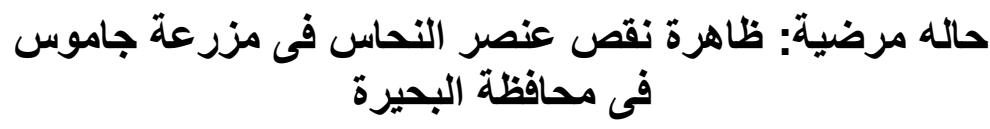

أمانس عبل الرحمن سلام ، عبل الرشبي فتحى عبل المغتح

أجريت هذه الدر اسة على قطيع من الجاموس(عدد 130) بمنطقة جناكلبس بمحافظة البحيرة

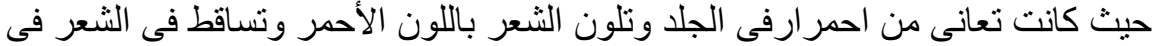

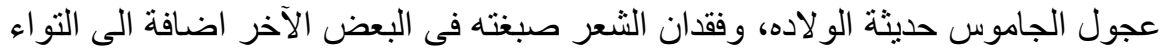

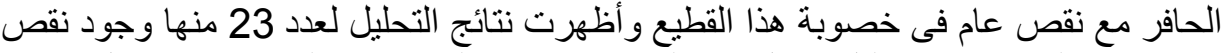

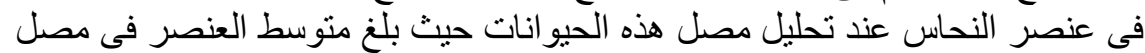

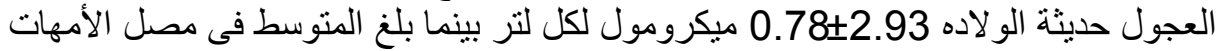

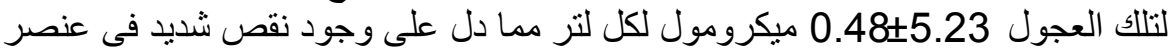

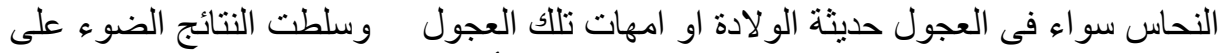

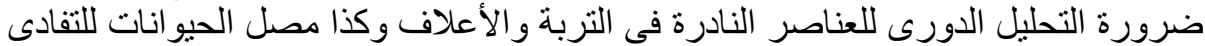
المبكر لمثل هذه المشكلة والتأكد من مستويات عنصر النحرة النحاس الطبيعية فى العلائق الحيو انية.

\section{SUMMARY}

This study was conducted on buffalo herd (130 animals, Janakleez district, Behaira Province) showing a red hair and skin, allopacia in newly born buffalo calves ageing from one day up to 15 days old. Clinical examination of the animals showed that the majority of buffaloes in the herd had rough hair coat, loss of hair pigmentation in addition to curled toe in some adult buffaloes). All the animals were sluggish in movement and had low fertility. The mean serum copper level recorded was $2.93 \pm 0.78 \mu \mathrm{mol} / \mathrm{L}$ in buffalo calves while serum dams revealed a mean value of $5.23 \pm 0.48 \mu \mathrm{mol} / \mathrm{L}$. Copper level in both 
neonates and their dams indicates a severe deficiency. The obtained results drew the attention for the importance of periodic analysis for serum, soil, and ration to avoid deficiency complications of trace elements early

Key words: Buffalo, copper, blood serum.

\section{INTRODUCTION}

Nutrition has a significant impact in animal production. Because trace elements that constitute an important part of animal nutrition have unique roles in mammals, their deficiencies can adversely affect animal health. Copper, one of the trace elements, is involved in numerous physiological functions such as haemoglobin formation, iron metabolism, and connective tissue metabolism (Hays and Swenson 1980). Copper deficiency is associated with numerous clinical signs, including anaemia, severe diarrhoea, weight loss or diminished weight gain, epiphyseal enlargement, change in hair colour, neonatal ataxia, and infertility (Maas and Smith, 2002). The manifestation of copper deficiency vary according to age,sex, and animal species beside the severity and duration of the deficiency. Also the copper is available to the animal becomes insufficient for all the metabolic processes involving copper as a result of inadequate intake, depletion of the body reserves, or interaction with metabolic antagonists, (Eric, 1977). In this study, copper deficiency in a buffalo herd showing some clinical signs on adults and their neonates was investigated.

\section{MATERIALS and METHODS}

\section{Animals:}

The study was conducted on buffalo herd $(n=130$, Janakleez district, Behaira Province) showing a red hair and skin, allopacia in newly born buffalo calves ageing from one day up to 15 days old in addition to curled toe in some adult buffaloes).

Twenty three animals used in the study were divided as the following:-

1- First group: Nine buffalo calves, 1-15day old age, suffering from diarrhea had a red hair and skin, allopacia

2- Second group: Nine dames refered to these calves, showed rough hair coat, grey hair around the eyes, and loss of hair pigmentation (red hair) 
3- Third group: Five clinically normal buffaloes.

Blood samples:

Blood samples were collected from the jugular vein of the investigated animals into vacutainer tubes for the determination of serum copper concentration. Serum copper, concentration was measured spectrophotometrically using a commercial kits according to Tietz, (1990).

Statistical analysis was performed using SPSS (2006) for Windows (Version 10.0; Microsoft). Duncan's New Multiple Range Test was used to determine differences among means.

\section{RESULTS}

Clinical examination of the animals showed that majority $(n=75)$ of buffaloes in the herd had rough hair coat, grey hairs around the eyes and loss of hair pigmentation. The animals were sluggish in movement, the herd had low fertility while the neonates had red skin, easly detached hair with allopacia in some animals.

In the affected neonates, the mean serum copper level was $2.93 \pm 0.78 \mu \mathrm{mol} / \mathrm{L}$ while serum dams revealed a mean value of $5.23 \pm 0.48 \mu \mathrm{mol} / \mathrm{L}$. The copper level in both neonates and their dams indicates a severe deficiency (Table 1). In adult buffaloes the mean values recorded was $5.23 \pm 0.48 \mu \mathrm{mol} / \mathrm{L}$ for buffalo dams versus $5.92 \pm 0.62 \mu \mathrm{mol} / \mathrm{L}$ for the third group (Table 1)

Table 1: Serum concentrationsa of copper, of calves and their buffalo dams $(\mu \mathrm{mol} / \mathrm{L})$

\begin{tabular}{|l|c|c|c|}
\hline \multicolumn{1}{|c|}{ Animal } & $\begin{array}{c}\text { Mean } \pm \text { SD } \\
\mu \mathrm{mol} / \mathrm{L}\end{array}$ & $\begin{array}{c}\text { Minimum } \\
\text { value }\end{array}$ & $\begin{array}{c}\text { Maximum } \\
\text { value }\end{array}$ \\
\hline $\begin{array}{l}\text { First group: } \\
\text { Buffalo calves }(\mathrm{n}=9)\end{array}$ & $2.93 \pm 0.78 \mathrm{a}$ & 2 & 4.2 \\
\hline $\begin{array}{l}\text { Second group: } \\
\text { Buffalo dams ( } \mathrm{n}=9)\end{array}$ & $5.23 \pm 0.48 \mathrm{~b}$ & 4.4 & 6.1 \\
\hline $\begin{array}{l}\text { Third group: Clinically normal } \\
\text { buffaloes }(\mathrm{n}=5)\end{array}$ & $5.92 \pm 0.62 \mathrm{~b}$ & 5 & 6.7 \\
\hline
\end{tabular}

Highly significant at $(\mathrm{P}>0.05)$

DISCUSSION 
Copper deficiency is characterised by clinical abnormalities such as poor growth, anaemia, epiphyseal enlargement, depigmentation of hair, and rough hair coat (Maas and Smith 2002; Woodbury et al., 2005). Similarly, rough hair coat, depigmentation of hair (in adult buffaloes), in addition of loss of the hair in the neonates, were obviously found in the affected animals.

Some cattle with inadequate serum $\mathrm{Cu}$ might have been mobilizing liver $\mathrm{Cu}$ and therefore could be moving toward a deficiency (Gadberry et al., 2003) that coincised with results of the present study which revealed a sharp decrease of $\mathrm{Cu}$ serum of the neonates and their dams (Table 1). When blood samples are used for copper determination, serum or plasma is preferred, (Naylor,1991) The normal serum copper concentration range is accepted as 10.99-18.84 $\mu \mathrm{mol} / \mathrm{L}$. Serum or plasma copper concentration of $6.28 \mu \mathrm{mol} / \mathrm{L}$ or less is considered as an evidence of clear deficiency. Values of 6.28 to $10.99 \mu \mathrm{mol} / \mathrm{L}$ are marginal (Maas and Smith 2002). Mortimer et al. (1999) suggested that serum copper concentrations less than $10.20 \mu \mathrm{moI} / \mathrm{L}$ indicate a potential deficiency. In the present farm, mean serum copper concentration $(5.23 \mu \mathrm{mol} / \mathrm{L})$, indicates that these animals suffered from a copper deficiency. Diagnosis of copper deficiency which based only on clinical examination is very difficult because clinical findings are non-specific. In this farm we noticed the clinical findings on the neonates and their dams which were confirmed by determination of their serum $\mathrm{Cu}$ concentration. Moreover both affected buffaloes in the second or the third groups (Table 1) have a mean serum copper concentration indicates a copper deficiency. Copper deficiency on these farms may be occurring due to low levels of $\mathrm{Cu}$ in the forage, low levels of $\mathrm{Cu}$ in the mineral supplement or poor mineral supplement intake, and (or) high levels of antagonistic minerals in the diet such as sulfur, iorn and (or) molybdenum (Mullis et al., 2003). More literatures reported that breed of animals affect $\mathrm{Cu}$ status (Zervas et al., 1990; Gooneratne et al., 1994; Du et al., 1996). In the present study buffalo breed may be more susceptible for $\mathrm{Cu}$ deficiency than other breeds. Differences between Aberdeen Angus and Simmental in biliary copper secretion (Gooneratne et al., 1994) may be indicative of breed differences in copper metabolism in cattle. Jersey's accumulated copper in their livers slightly than Holsteins when given the same copper -rich diet, (Du et al., 1996).

Goats retain less copper in their livers than sheep when exposed to excesses $\mathrm{Cu}$ presumably because they share with cattle a propensity for biliary copper secretion (Zervas et al., 1990). 
The farm responded well after addition of copper sulphate to the drinking water which demonstrated in diminishing of the clinical signs and improvement in neonates and adult buffaloes health. The fertility was significantly improved.

The obtained results drew the attention for the importance of periodic trace elements analysis for serum, soil, and ration to avoid deficiency complications of these elements early.

\section{REFERENCES}

Du, Z.; Hemken, R.W. and Harmon, R.J. (1996): Copper metabolism of Holstein and Jerse cows and heifers fed diets high in cupric sulphate or copper proteinate. Journal of Dairy Science 79: 1873-1880.

Eric, J.U. (1977): Trace elements in human and animal nutrition. $4^{\text {th }}$ ed. Academic press New York Sanfrancisco London pp. 75-106.

Gadberry, M.S.; Troxel, T.R and Davis1, G.V. (2003): Blood Trace Mineral Concentrations of Cows and Heifers from Farms Enrolled in the Arkansas Beef Improvement Program Arkansas Animal Science Department Report pp.50-52.

Gooneratne, S.R.; Symonds, H.W.; Baile, J.V. and Christensen, D.A. (1994): Effects of dietary copper, molybdenum and sulpher on biliary copper and zinc secretion in Simmental and Angus cattle. Canadian Journal of Animal Science 74: 315-325.

Hays, V.W. and Swenson, M.J. (1980): Minerals and bones. In: Dukes' Physiology of Domestic Animals.

Humphries, W.R. (1980): Control of Hypocupraemia in cattle by addition of copper to water supplies. Veterinary Record 106: 359-362.

Maas, J. and Smith B.P. (2002): Copper deficiency in ruminants. In: Large Animal Internal Medicine edited by B.P. Smith, St 138 Louis, London, Philadelphia, Sydney, Toronto MosbyInc., pp.783-786.

Mortimer, R.G.; Dargatz, D.A. and Corah, L.R. (1999): Forage analyses from cow-calf herds in 23 states. USDA: APHIS: VS, Centers for Epidemiology and Animal Health. Fort Collins, CO.

Mullis, L.A.; Spears, J.W. and McCraw, R.L. (2003): Estimated copper requirements of Angus and Simmental heifers J. Anim. Sci. 81:865-873. 
Naylor, J.M. (1991): Nutritional problems in cow / calf practice. In: Large Animal Clinical Nutrition edited by J.M. Naylor, S.R. Ralston, St. Louis, Baltimore, Boston, Chicago, London, Philadelphia, Sydney, Toronto Mosby Inc., pp. 215-223.

SPSS (2006): For Windows (version 10.0).

Tietz, NW. (1990): Clinical guide to laboratory tests, $2^{\text {nd }}$ ed Philadelphia, Pa: WB Saunders company, pp. 444-447.

Woodbury, M.R.; Feist, M.S.; Clark, E.G. and Haigh, J.E. (2005): Osteochondrosis and epiphyseal bone abnormalities zinc deficiencies in dairy cows, calves, heifers, and bulls. Vet. Med. - Czech, 50: 390-400.

Zervas, V.; Nikolau, E. and Mantzios, A. (1990): Comparative study of chronic copper poisoning in lambs and young goats. Animal Production 50: 479-506. 